\title{
PENERAPAN COST PLUS PRICING DENGAN PENDEKATAN FULL COSTING DALAM MENENTUKAN HARGA JUAL PADA UD. LYLY BAKERY LAMONGAN
}

\section{ARTICLE INFO}

\section{Article history:}

Received 9 Januari 2019

Received in Revised 19 April 2019

Accepted 4 April 2019

Keywords:

Cost Plus Pricing, full

costing, product sales price

ABSTRACT

The purpose of this study is to investigate how fixing the selling price at UD. Lyly Bakery Lamongan with a sales price under Cost Plus Pricing method. The method used in this study is a quantitative descriptive analysis method. The result showed the pricing strategy of selling UD. Lyly Bakery Lamongan is a joint product pricing strategy and price adjusment strategies. The conclusion of this study indicate the selling price fixing Cost Plus Pricing method with a full costing approach in the years 2013 - 2015 selling price lower than the selling price set by UD. Lyly Bakery Lamongan, but in 2015 there are two kinds of products selling price set UD. Lyly Bakery Lamongan namely bakery products bakery abd donut.
\end{abstract}

Penelitian ini bertujuan untuk untuk mengetahui cara penetapan harga jual yang tepat dengan metode Cost Plus Pricing pada UD. Lyly Bakery Lamongan dan anaka cabangnya. Metode yang digunakan dalam penelitian ini adalah metode analisis deskriptif kuantitatif. Hasil penelitian menunjukkan strategi penetapan harga jual dari UD. Lyly Bakery Lamongan adalah strategi penetapan harga produk gabungan dan strategi penyesuaian harga. Kesimpulan dalam penelitian ini menunjukkan penetapan harga jual dengan metode Cost Plus Pricing dengan pendekatan full costing tahun 2013 - 2015 harga jualnya lebih rendah dibandingkan dengan harga jual yang ditetapkan oleh UD. Lyly Bakery Lamongan, namun pada tahun 2015 ada dua jenis produk bakery dan donat yang harga jualnya mendekati harga jual yang ditetapkan oleh UD. Lyly Bakery Lamongan.

AKUISISI : Jurnal Akuntansi

Website : http://www.fe.ummetro.ac.id/ejournal/index.php/JA

This is an open access article distributed under the terms of the Creative Commons Attribution 4.0 International License, which permits unrestricted use, distribution, and reproduction in any medium, provided the original work is properly cited.

E-mail address: sutrihandayani99@gmail.com Peer review under responsibility of Akuisisi : Accounting Journal. 2477-2984. http://dx.doi.org/10.24217 


\section{PENDAHULUAN}

Perusahaan merupakan organisasi yang mempunyai tujuan jangka panjang maupun jangka pendek. Salah satu tujuan yang penting untuk dicapai perusahaan adalah pencapaian laba yang optimum. Untuk menjamin agar usaha perusahaan mampu menghasilkan laba, maka manajemen perusahaan harus mampu merencanakan dan mengendalikan dengan baik antara pendapatan dan biaya.

Harga jual merupakan faktor penting dalam bisnis perusahaan. Konsumen seringkali mempertimbangkan harga dalam membuat keputusan dalam membeli sebuah produk. Harga mempunyai peranan penting dalam pengambilan keputusan pembelian barang konsumen.

Menurut Kotler dan Keller dalam Moray (2009:439) harga jual adalah sejumlah uang yang dibebankan atas suatu produk atau jasa, atau jumlah dari nilai yang ditukar konsumen atas manfaat-manfaat, karena memiliki atau menggunakan produk atau jasa tersebut.

Ada tiga metode yang dapat diambil oleh pihak manajemen dalam perencanaan dan pengambilan keputusan dalam menentukan harga jual, yaitu dengan metode Cost Plus Pricing menggunakan pendekatan full costing, variable costing, metode mark up pricing dan metode penenentuan harga oleh produsen.

Untuk menentukan harga jual dengan tepat, maka harus diketahui harga pokok produksi, karena harga pokok produksi adalah dasar bagi perusahaan untuk menentukan harga jual. Harga pokok produksi merupakan komponen biaya yang langsung berhubungan dengan produksi. Penetapan harga pokok produksi mempunyai peranan yang penting pada suatu perusahaan, sebab dari harga pokok dapat dibuat analisa rencana dan kekuatan pemasaran, penentuan harga jual dan sebagai perencanaan laba perusahaan.

Dalam menentukan harga pokok produksi dapat menggunakan dua metode yaitu : metode full costing dan variable cossting. Pada metode full costing semua biaya - biaya yang diperhitungkan baik yang bersifat tetap maupun variabel. Sedangkan dalam metode variable costing untuk penentuan harga pokok produksi hanya biaya - biaya produksi variable saja yang dimasukkan dalam persediaaan dan biaya pokok produksi.

UD. Lyly Bakery merupakan salah satu usaha perusahaan yang memproduksi bermacam - macam jenis kue yaitu bakery, cake, pastry, tart, kue manis dan kue basahan. Strategi penerapan harga yang dilakukan oleh perusahaan Lyly Bakery yaitu strategi penetapan harga produk gabungan, strategi penyesuaian harga, dalam hal ini adalah penetapan harga diskon yang meliputi diskon berdasarkan jumlah dan diskon berdasarkan waktu dan penetapan harga psikologi. Usaha ini hendaknya mampu menetapkan harga jual yang tepat sehingga nantinya dapat bersaing dengan usaha lain yang sejenis.

Berdasarkan latar belakang tersebut, maka dapat dirumuskan masalah sebagai berikut bagaimana cara penetapan harga jual yang tepat dengan metode Cost Plus Pricing pada UD. Lyly Bakery Lamongan dan anak cabangnya.

Tujuan penelitian ini adalah untuk mengetahui cara penetapan harga jual yang tepat dengan metode Cost Plus Pricing pada UD. Lyly Bakery Lamongan dan anak cabangnya.

Mulyadi (2014:7) menyatakan bahwa akuntansi biaya adalah proses pencatatan, penggolongan , peringkasan dan penyajian biaya, pembuatan dan penjualan produk atau jasa, dengan cara - cara tertentu, serta penafsiran terhadapnya. Objek kegiatan akuntansi biaya adalah biaya.

Mulyadi (2014:17) menyatakan bahwa penentuan kos produksi adalah cara memperhitungkan unsur-unsur biaya ke dalam kos produksi. Dalam memperhitungkan unsur- 
unsur biaya ke dalam kos produksi, terdapat dua pendekatan yaitu full costing dan variable costing. Full costing merupakan metode penentuan kos produksi yang memperhitungkan semua unsur biaya produksi ke dalam kos produksi, yang terdiri dari biaya bahan baku, biaya tenaga kerja langsung, dan biaya overhead pabrik, baik yang berperilaku variabel maupun tetap.

Mulyadi (2014:18) menyatakan variable costing merupakan metode penentuan kos produksi yang hanya memperhitungkan biaya produksi yang berperilaku produksi variabel ke dalam kos produksi yang terdiri dari biaya bahan baku, biaya tenaga kerja langsung, dan biaya overhead pabrik variabel.

Kotler dan Keller dalam Moray (2009:439) menyatakan harga jual adalah sejumlah uang yang dibebankan atas suatu produk atau jasa, atau jumlah dari nilai yang ditukar konsumen atas manfaat-manfaat, karena memiliki atau menggunakan produk atau jasa tersebut.

Kotler dan Keller dalam Moray (2009:138) menyatakan bahwa tujuan penetapan harga, yaitu: kelangsungan hidup, laba sekarang maksimum, pendapatan sekarang dan maksimum, pertumbuhan penjualan maksimum, skimming pasar maksimum, kepemimpinan mutu produk.

Menurut Swastha dalam Moray (2014:1275) bahwa metode penentuan harga jual yang berdasarkan biaya dalam bentuk yang paling sederhana, yaitu :Cost Plus Pricing Method, penentuan harga jual Cost Plus Pricing, biaya yang digunakan sebagai dasar penentuan, dapat di definisikan sesuai dengan metode penentuan harga pokok produk yang digunakan, Mark up Pricing Method, penentuan harga jual dengan Mark up Pricing merupakan, penetapan harga dimana harga tertentu ditetapkan dengan jelas menambahkan suatu prosentase tetap di atas biaya produksi, Penentuan harga oleh produsen, dalam metode ini, harga yang ditetapkan oleh perusahaan awal dari rangkaian harga yang ditetapkan oleh perusahaan-perusahaan lain dalam saluran distribusi. Karena itu, penetapan harga oleh produsen memegang peranan penting dalam menentukan harga akhir barang.

Menurut Garisson, et al., ( Terjemahan, 2013:125) menyatakn bahwa Cost Plus Pricingadalah proses penentuan harga jual dengan cara menghitung biaya produksi per unit, memutuskan berapa laba yang diinginkan, kemudian menentukan harga jual.

Menurut Kamaruddin dalam Moray (2014:1376) menyatakan bahwa biaya (cost) merupakan komponen penting yang harus dipertimbangkan dalam penentuan harga jual produk atau jasa. Harga jual produk atau jasa pada umumnya ditentukan dari jumlah semua biaya ditambah jumlah tertentu yang disebut dengan mark up. Cara penentuan harga jual tersebut dikenal dengan pendekatan Cost-plus (Cost Plus Approoach). Pengertian Cost Plus, adalah nilai biaya tertentu ditambah dengan kanaikan (mark-up) yang ditentukan. Di dalam konsep perhitungan harga pokok dikenal dua pendekatan yaitu: Perhitungan harga pokok penuh (full costing). Dalam pendekatan ini yang dimasukkan sebagai komponen harga pokok produk adalah seluruh biaya-biaya yang berkaitan dengan pembuatan produk baik yang bersifat variabel maupun yang bersifat tetap adalah Bahan baku langsung, upah langsung, biaya overhead pabrik variabel, dan biaya overhead pabrik - tetap, Perhitungan harga pokok variable (variable costing). Dalam pendekatan ini yang dimasukkan sebagai komponen harga pokok produk adalah seluruh biaya-biaya yang bersifat variable. Biaya variable tersebut adalah Biaya bahan baku langsung, biaya tenaga kerja langsung, biaya penjualan variabel, biaya umum dan administrasi variable.

Menurut Mulyadi (2001:48) menyatakan biaya penuh atau full cost merupakan total biaya yang bersangkutan dengan informasi. Jika objek informasi berupa produk, full cost merupakan biaya yang bersangkutan dengan produk tersebut. Perhitungan full cost atau produk dipengaruhi oleh metode penentuan cost produk yang digunakan full costing atau variable costing, activy based costing.

Dalam penentuan harga jual normal atau biasa disebut dengan Cost Plus Pricing, harga jual harus dapat menutup biaya penuh ditambah laba yang wajar. Jika pendekatan full 
costing yang digunakan dalam penentuan harga pokok produksi, harga jual produk harus menutupi biaya penuh yang merupakan jumlah biaya produksi dan biaya non produksi, ditambah dengan laba yang wajar. Jika pendekatan variable costing digunakan dalam penentuan harga pokok produksi, harga jual produk harus dapat menutup taksiran biaya penuh, yang merupakan jumlah biaya variabel (biaya produksi variabel dan biaya non produksi tetap) yang akan dikeluarkan, ditambah dengan laba wajar (Mulyadi 2001:54).

\section{METODE PENELITIAN}

Penelitian dimulai pada bulan Januari sampai bulan Juni 2016. Penelitian ini dilaksanakan di UD. Lyly Bakery Lamongan dan anak cabang, yang beralamatkan di Jl. Sunan Drajat No. 52 Lamongan. Peneliti menggunakan jenis penelitian deskriptif kuantitatif dengan pendekatan studi kasus, yang berisi gambaran umum perusahaan dan informasi operasi perusahaan dengan data kuantitatif yang berupa data biaya produksi dan data penjualan untuk metode perhitungan harga jual Cost Plus Pricing dengan pendekatan full costing pada UD. Lyly Bakery Lamongan dan anak cabang.

Populasi dari penelitian ini adalah semua data penjualan dan biaya produksi yang terdiri dari biaya bahan baku, biaya tenaga kerja, dan biaya overhead pabrik yang bersifat variable maupun tetap di UD. Lyly Bakery Lamongan. Sampel dalam penelitian ini adalah data penjualan induk dan anak selama tahun 2013-2015, data biaya produksi tahun 20132015 yang terdiri dari biaya bahan baku, biaya tenaga kerja, dan biaya overhead pabrik. Teknik penarikan sampel yang digunakan dalam penelitian ini adalah teknik purposive sampling.

Metode pengumpulan data pada penelitian ini terdiri dari data primer yang diperoleh dari hasil wawancara langsung kepada Manajer UD. Lyly Bakery Lamongan, sedangkan data sekunder dalam penelitian ini adalah data penjualan dan data biaya produksi roti selama tahun $2013-2015$.

Adapun teknik pengumpulan data, Peneliti menggunakan studi kepustakaan, studi lapangan yang diperoleh dari hasil wawancara dan dokumentasi .

Operasional variabel dalam penelitian ini adalah Cost Plus Pricing (X1), full costing (X2), harga jual. Sedangkan metode analisis data dilakukan dengan cara menentukan biaya biaya produksi yang terdiri dari biaya bahan baku, biaya tenaga kerja langsung, dan biaya overhead pabrik, menghitung besarnya biaya produksi dengan metode full costing, menentukan harga jual Cost Plus Pricing dengan pendekatan full costing, dan menganalisis data dengan melekukan perbandingan antara teori dengan hasil penelitian sehingga dapat ditarik kesimpulan mengenai penetapan harga jual dengan metode Cost Plus Pricing dengan pendekatan full costing pada UD. Lyly Bakery Lamongan dan anak cabang.

\section{PEMBAHASAN}

UD. Lyly Bakery adalah perusahaan yang memproduksi bermacam - macam produk olahan kue yaitu bakery, cake, pastry, dan donuts yang beralamatkan di Jl. Sunan Drajat 52 Lamongan.

Dari hasil obervasi dan pengolahan data di atas dapat diketahui bahwa perhitungan selama tahun 2013 - 2015 menggunakan metode Cost plus pricing dengan pendekatan full costing yaitu menghitung seluruh pengeluaran yang terjadi mulai dari biaya bahan baku, biaya tenaga kerja langsung, biaya tenaga kerja tak langsung, biaya overhead pabrik, dan menghitung harga pokok produksi kemudian menetapkan harga jual dengan menambahkan laba yang dinginkan oleh perusahaan dapat menghasilkan harga jual yang lebih rendah dibandingkan dengan harga jual yang ditetapkan oleh UD. Lyly Bakery Lamongan.

Hal ini menunjukkan bahwa dengan metode Cost Plus Pricing dengan pendekatan full costing sangat tepat diterapkan pada usaha - usaha roti, sehingga harga jual yang dicapai UD. 
Lyly Bakery Lamongan dapat bersaing dengan produk sejenis yang ada di pasaran, namun tetap mendapatkan laba yang sesuai dengan laba yang diinginkan perusahaan.

Perhitungan harga jual Cost Plus Pricing dengan pendekatan full costing pada tahun 2013, dapat diketahui bahwa harga jual Cost Plus Pricing dengan pendekatan full costing untuk tiap jenis produk harga jualnya lebih rendah dibandingkan dengan harga jual yang ditetapkan oleh UD. Lyly Bakery Lamongan, itu terbukti dari perhitungan harga jual untuk produk bakery dengan metode Cost Plus Pricing sebesar Rp. 2.860, untuk produk pastry sebesar Rp. 1.592, produk donat sebesar RP. 2.314, produk tawar sebesar Rp. 10.098, produk cake sebesar Rp. 3.322, dan produk kue basah sebesar Rp. 4.320.

Perhitungan harga jual Cost Plus Pricing dengan pendekatan full costing tahun 2014, maka dapat diketahui bahwa perhitungan harga jual dengan metode Cost Plus Pricing dengan pendekatan full costing harga jualnya lebih rendah dibandingkan dengan harga jual yang ditetapkan oleh UD. Lyly Baker Lamongan. Untuk produk bakery harga jual Cost Plus Pricing sebesar Rp. 3.245, produk pastry sebesar Rp. 2.453, produk donat sebesar Rp. 1.970, produk tawar sebesar Rp. 10.430, produk cake sebesar Rp. 3.580, dan untuk produk kue basah harga jual Cost Plus Pricing sebesar Rp. 4.214.

Perhitungan harga jual Cost Plus Pricing dengan pendekatan full costing pada tahun 2015, maka dapat diketahui rincian harga jual tiap jenis produk. Untuk produk bakery harga jual Cost Plus Pricing diketahui sebesar Rp. 3.648, untuk produk pastry sebesar Rp. 2.644, untuk produk donat sebesar Rp. 2.194, untuk produk tawar sebesar Rp. 10.865, untuk produk cake sebesar Rp. 3.829, dan untuk produk kue basah sebesar Rp. 4.658.

Namun ada dua jenis produk yang harga jualnya mendekati harga jual yang ditetapkan oleh UD. Lyly Bakery Lamongan yaitu produk bakery dan donat. Untuk produk bakery harga jual Cost Plus Pricing diketahui sebesar Rp. 3.468, sedangkan harga jual di UD. Lyly Bakery Lamongan sebesar Rp. 3.500, sehingga diketahui selisih Rp. 32. Untuk produk donat diketahui harga jual Cost Plus Pricing sebesar Rp. 2.194, sedangkan harga jual di UD. Lyly Bakery Lamongan sebesar Rp. 2.250, sehingga selisih harga jual sebesar Rp. 56.

\section{PENUTUP}

\section{KESIMPULAN}

Berdasarkan analisa data dan pembahasan yang dilakukan oleh peneliti selama tahun 2013 - 2015, maka dapat diperoleh kesimpulan yaitu : Perhitungan harga jual per unit pada UD. Lyly Bakery Lamongan dengan metode Cost Plus Pricing dengan pendekatan full costing tahun 2013, harga jualnya lebih rendah dibandingkan dengan harga jual yang ditetapkan oleh UD. Lyly Bakery Lamongan, itu terbukti dari hasil perhitungan harga jual Cost Plus Pricing per unit untuk produk bakery sebesar Rp. 2.860, produk pastry sebesar Rp. 2.314, produk donat sebesar Rp. 1.592, produk tawar sebesar Rp. 10.098, produk cake sebesar Rp. 3.322, dan produk kue basah sebesar Rp. 4.320. Pada tahun 2014 perhitungan harga jual dengan metode Cost Plus Pricing dengan pendekatan full costing pada UD. Lyly Bakery Lamongan mempunyai kesamaan dengan tahun 2013 yaitu harga jualnya lebih rendah dibandingkan dengan harga jual yang ditetapkan oleh UD. Lyly Bakery Lamongan, yang bisa dilihat dari hasil perhitungan harga jual per unit untuk produk bakery sebesar Rp. 3.245, produk pastry sebesar Rp. 2.453, produk donat sebesar Rp. 1.930, produk tawar sebesar Rp. 10.430, produk cake sebesar Rp. 3.580, dan untuk produk kue basah sebesar Rp. 4.214. Perhitungan harga jual Cost Plus Pricing dengan pendekatan full costing pada tahun 2015, ada dua jenis produk yang harga jualnya mendekati harga jual yang ditetapkan oleh UD. Lyly Bakery lamongan yaitu produk bakery dan donat. Untuk produk bakery diketahui harga jual Cost Plus Pricing sebesar Rp. 3.468 mempunyai selisih Rp. 32 bila dibandingkan dengan harga jual di UD. Lyly Bakery Lamongan, sedangkan untuk produk donat harga jual Cost Plus Pricing diketahui sebesar Rp. 2.194 juga mempunyai selisih Rp. 54 dengan harga jual 
yang ditetapkan oleh UD. Lyly Bakery Lamongan. Jadi dapat disimpulkan bahwa selama tahun 2013 - 2015 perhitungan harga jual dengan metode Cost Plus Pricing dengan pendekatan full costing harga jualnya lebih rendah dibandingkan dengan harga jual yang ditetapkan oleh perusahaan.

\section{SARAN}

Dari kesimpulan yang berhubungan dengan pembahasan, maka dapat ditemukan saran - saran yang diharapkan dapat bermanfaat bagi perusahaan sebagai bahan pertimbangan adalah sebagai beikut Perhitungan untuk menentukan harga jual produk dengan menggunakan metode Cost Plus Pricing dengan pendekatan full costing dapat mengidentifikasikan secara signifikan biaya - biaya produksi per produk, UD. Lyly Bakery Lamongan dapat mempertimbangkan cara penentuan harga jual produk berdasarkan metode Cost Plus Pricing dengan pendekatan full costing dimana harga jual yang ditentukan lebih rendah daripada harga jual yang ditentukan perusahaan, namun tetap memiliki laba yang sesuai dengan laba yang diharapkan oleh perusahaan.

\section{DAFTAR PUSTAKA}

Garisson, Noreen dan Brewer. (2013). Akuntansi Manajerial, Edisi 14. Salemba Empat, Jakarta.

Moray, Jessica Claudia., dkk. (2014). Penetapan Harga Jual dengan Cost Plus Pricing menggunakan Pendekatan Full Costing : Pada UD. Gladys Bakery. Jurnal EMBA. Volume 2; 1272-1283.

Mulyadi. (2001). Akuntansi Manajemen. Edisi 1. UPP STIM YKPN, Yogyakarta.

--------. (2014). Akuntansi Biaya. Edisi 5 . UPP STIM YKPN, Yogyakarta. 